\title{
Methodology of information relevance assessment
}

\author{
Bychkovskyi V., Reutska Yu. ${ }^{*}$ \\ National Technical University of Ukraine "Igor Sikorsky Kyiv Polytechnic Institute", Kyiv, Ukraine \\ National University of Life and Environmental Sciences of Ukraine, Kyiv, Ukraine
}

Received: $01.02 .2021 \quad$ Accepted: 15.03.2021

\begin{abstract}
The paper considers a methodology that makes it possible to determine the relationship between useful, distracting and interfering information. The proposed methodology allows you to evaluate the relevance of information supplied to a specialist. The situation when a specialist, based on the information received, makes certain decisions and performs the assigned tasks is considered. The regularity of the change in the probability of performing these functions on the amount of information received and information capacity has been established. The regularity of the change in the probability of performing these functions on the amount of information received and information capacity has been established. It is shown that the equation of information dynamics is an information analogue of T. Malthus's population model. This makes it possible to use well-known methods of analysis and extend the results obtained to other mathematical models. The procedure for selecting models that take into account various restrictive effects is considered. The factor of self-limitation is taken into account. The transition to an informational analogue of the Quetelet-Verhulst population model is justified. The external limiting factor is considered in the context of the influence of distracting and disturbing information. A predictive model for determining the pattern of changes in information ability is proposed. This model takes into account the speed of information flow under ideal conditions and the destructive influence of distracting and interfering information. The procedure for using the model is reviewed. This procedure provides an introduction to the calculations additional variable to take into account the influence of distracting and interfering information. The regularity of the change in the additional value and its relationship with information capabilities have been determined. It allows you to go to the procedure for finding out the potential value of the relevance indicator. A relationship has been established to determine the relevance indicators, which make it possible to take into account the potential amount of useful, distracting and interfering information. The relationship between the current and established values of relevance indicators has been established. The classification of the effects of distracting and interfering information is carried out. Relevance characteristics for the prevailing equal and weak influence of interfering and distracting information compared to useful information are analyzed. Methodology of using the relevance characteristics is considered. The ratios that make it possible to quickly assess the relevance indicator at predetermined control points and to determine the time to reach the control values of the observed values are established. The situation that arises under very strong and very weak influences of distracting and interfering information is analyzed.
\end{abstract}

Key words: information, relevance, information ability, method of analogies, classification of impacts.

\section{Методика оцінки релевантності інформації}

\section{Бичковський В. О., Реутська Ю. Ю.}

Національний технічний університет України “Київський політехнічний інститут імені Ігоря Сікорського”, Київ, Україна Національний університет біоресурсів і природокористування України , Київ, Україна

\begin{abstract}
Анотація. У роботі розглянуто методику, яка дає можливість визначити співвідношення між корисною, відволікаючою та заважаючою інформацією. Запропонована методика дозволяє оцінити релевантність інформації, що надходить до фахівця. Розглянуто ситуацію, коли фахівець на підставі отриманої інформації приймає певні рішення та виконує поставлені завдання. Встановлено закономірність зміни ймовірності виконання вказаних функцій від кількості отриманої інформації та інформаційної спроможності. З'ясовано, що у разі оперування швидкістю надходження інформації доцільно складати рівняння інформаційної динаміки на підставі аналізу закономірності зміни інформаційної спроможності. Показано, що рівняння інфформаційної
\end{abstract}

\footnotetext{
Corresponding Author: Reutska Yuliia Yuriivna. Tel. +38(093) 547-58-02. E-mail: reutska_rt@ukr.net National University of Life and Environmental Sciences of Ukraine, 16a Heroyiv Oborony St., 15th building of NUBiP, Kyiv, Ukraine, 03041.

Відповідальний автор: Реутська Юлія Юріївна. Тел. +38(093) 547-58-02. E-mail: reutska_tt@ukr.net Національний університет біоресурсів і природокористування України, вул. Героїв Оборони, 16а, навчальний корпус 15, Київ, Україна, 03041.
} 
динаміки є інформаційним аналогом популяційної моделі Т. Мальтуса, що дає можливість скористатися відомими методами аналізу та поширити отримані результати на інші математичні моделі. Розглянуто процедуру вибору моделей, в яких враховуються різноманітні обмежувальні впливи. Враховано фактор самолімітування та обґрунтовано перехід до інформаційного аналогу популяційної моделі Кетле-Ферхюльста. Фактор зовнішнього лімітування розглянуто у контексті впливу відволікаючої та заважаючої інформації. Запропоновано прогнозну модель для визначення закономірності зміни інсормаційної спроможності, яка враховує швидкість надходження інформації в ідеальних умовах та деструктивний вплив відволікаючої і заважаючої інформації. Розглянуто процедуру використання моделі, яка передбачає введення у розрахунки додаткової змінної величини для врахування впливу відволікаючої та заважаючої інформації. Визначено закономірність зміни додаткової величини та її зв'язок з інформаційними спроможностями, що дає можливість перейти до процедури з'ясування потенційно можливого значення показника релевантності. Встановлено співвідношення для визначення показників релевантності, які дають можливість враховувати потенційну кількість корисної, відволікаючої та заважаючої інформації. Встановлено залежність між поточним та усталеним значеннями показників релевантності. Проведено класифікацію впливів відволікаючої та заважаючої інформації. Проаналізовано характеристики релевантності для превалюючого рівнозначного та непревалюючого впливів заважаючої та відволікаючої інфрормації порівняно із корисною інформацією. Розглянуто методику використання характеристик релевантності. Встановлено співвідношення, які дають можливість провести оперативну оцінку показника релевантності у заздалегідь визначених контрольних точках та з'ясувати час досягання контрольних значень величин, що спостерігаються. Проаналізовано ситуацію, яка виникає за умови дуже сильних та дуже слабких впливів відволікаючої та заважаючої інформації.

Ключові слова: інформація, релевантність, інформаційна спроможність, метод аналогій, класифікація впливів.

\title{
Методика оценки релевантности информации
}

Бычковский В. А., Реутская Ю. Ю.

Национальный технический университет Украины "Киевский политехнический институт имени Игоря Сикорского", Киев, Украина

Национальный университет биоресурсов и природопользования Украины, Киев, Украина

\begin{abstract}
Аннотация. В работе рассмотрена методика, которая дает возможность определить соотношение между полезной, отвлекающей и мешающей информацией. Предложенная методика позволяет оценить релевантность информации, поступающей к специалисту. Рассмотрена ситуация, когда специалист на основании полученной информации принимает определенные решения и выполняет поставленные задачи. Установлена закономерность изменения вероятности выполнения указанных функций от количества полученной информации и информационной способности. Установлено, что в случае оперирования скоростью поступления информации целесообразно составлять уравнения информационной динамики на основании анализа закономерности изменения информационной способности. Показано, что уравнение информационной динамики является информационным аналогом популяционной модели Т. Мальтуса, что дает возможность воспользоваться известными методами анализа и распространить полученные результаты на другие математические модели. Рассмотрена процедура выбора моделей, в которых учитываются различные ограничивающие воздействия. Учтен фрактор самолимитирования и обоснован переход к информационному аналогу популяционной модели Кетле-Ферхюльста. Фактор внешнего лимитирования рассмотрен в контексте влияния отвлекающей и мешающей информации. Предложена прогнозная модель для определения закономерности изменения информационной способности, которая учитывает скорость поступления информации в идеальных условиях и деструктивное влияние отвлекающей и мешающей информации. Рассмотрена процедура использования модели, которая предусматривает введение в расчеты дополнительной переменной величины для учета влияния отвлекающей и мешающей информации. Определена закономерность изменения дополнительной величины и ее связь с информационными способностями, что позволяет перейти к процедуре выяснения потенциально возможного значения показателя релевантности. Установлено соотношение для определения показателей релевантности, которые дают возможность учитывать потенциальное количество полезной, отвлекающей и мешающей информации. Установлена зависимость между текущим и установившимся значениями показателей релевантности. Проведена классификация воздействий отвлекающей и мешающей информации. Проанализированы характеристики релевантности для превалирующего, равнозначного и непревалирующего влияния мешающей и отвлекающей информации по сравнению с полезной информацией. Рассмотрена методика использования характеристик релевантности. Установлены соотношения, которые дают возможность провести оперативную оценку показателя релевантности в заранее определенных контрольных точках и установить время достижения контрольных значений величин, которые наблюдаются. Проанализирована
\end{abstract}


ситуация, которая возникает при очень сильных и очень слабых воздействиях отвлекающей и мешающей информации.

Ключевые слова: информация, релевантность, информационная способность, метод аналогий, классификация воздействий.

\section{Bemyn}

Сучасний етап розвитку суспільства характеризується широким використанням інформації різного типу, виду та характеру. У прикладних та фундаментальних дослідженнях все більше уваги приділяється аналізу процесів у інформаційному середовищі, використанню інформаційних ресурсів та ефрективності інформаційної взаємодії $[1,2,3]$. Важливою частиною таких досліджень $€$ визначення способів роботи з інформацією, особливостей когнітивних процесів в умовах невизначеності та десіциту інформації $[4,5]$. Розробляється також концепція поглядів на об'єкти дослідження з позицій теорії інформації та ролі фахівця, що виконує поставлену задачу і приймає рішення [6].

Суттєвим фактором $є$ те, що фахівець працює у інформаційному середовищі, заповненому як корисною, так і відволікаючою та заважаючою інформацією. Ефективність роботи фахівця залежить від його інфрормаційної компетентності, уміння використовувати необхідну інформацію та релевантності інформації. Дослідженням, які стосуються проблем релевантності, приділяється достатньо уваги [7, 8, 9]. Необхідно зауважити, що їх преважна частина стосується якісного, а не кількісного аналізу. Таким чином, не представляється можливим проводити порівняльний аналіз на певних метричних шкалах. Отже, розробку методики оцінки релевантності інфрормації, яка забезпечує отримання кількісних показників, необхідно розглядати як актуальну задачу.

Метою роботи $є$ отримання показників, які характеризують співвідношення між корисною, заважаючою та відволікаючою інформацією, що надходить до фахівця. Необхідно виявити закономірності зміни кількості інформації, встановити співвідношення для визначення показника релевантності, провести класифікацію заважаючих та відволікаючих впливів, з'ясувати прогнозні тенденції на підставі аналізу поточного та усталеного значень показника релевантності.

\section{II Матеріал і методи дослідження}

Для розв'язання поставленої задачі скористуємося теоретико-інформаційним підходом та приймемо до уваги, що одним з головних засобів досягнути поставленої мети - це індукція і аналогія [10]. Необхідно зауважити, що інформація використовується фахівцем з певною метою, а процес інформаційного забезпечення фрахівця розгортається у часі. Для визначення закономірностей надходження інформації до фахівця застосовуються різноманітні прогнозні моделі [11]. Більшість із них враховують фактор самолімітування, але зовнішнє лімітування, яке зумовлене відволікаючою та заважаючою інформацією, залишається поза розгляду. Якщо прийняти до уваги, що прогнозні моделі складено на підставі методу аналогій, то стає зрозумілою доцільність використання даного методу, але з урахуванням впливу відволікаючої та заважаючої інформації.

Приймемо до уваги, що фахівець є особою, яка приймає певні рішення та виконує поставлені завдання. Ймовірність $P$ виконання вказаних функцій залежить від кількості інформації $I_{1}$, що надходить до фахівця. В процесі надходження інформації ймовірність $P$ збільшується та асимптотично наближається до одиниці. Таким чином, можна записати

$$
d P=K(1-P) d I_{1},
$$

де $K$ - константа швидкості зміни $P$ за рахунок збільшення $I_{1}$.

Якщо позначити $g=1-P$, тобто перейти до зворотної події, то на підставі формули (1) можна записати

$$
d g=-K g d I_{1}
$$

Оскільки $I_{1}=\ln N_{1}$, де $N_{1}$ - інформаційна спроможність, то із залежності (2) знаходимо 


$$
\frac{d g}{g}=-K \frac{d N_{1}}{N_{1}} .
$$

Інтегруючи ліву частину рівняння (3) від 1 до $g$, праву від 1 до $N_{1}$, визначаємо $\ln g=-K \ln N_{1}$, або

$$
\begin{gathered}
g=N_{1}^{-K}, \\
P=1-N_{1}^{-K} .
\end{gathered}
$$

Аналіз залежностей (4), (5) показує, що для визначення $g$ та $P$ достатньо визначити $N_{1}$.

На підставі співвідношення (5) знаходимо

$$
\left.\frac{d P}{d N_{1}}\right|_{N_{1}=1}=K .
$$

Аналіз залежностей (5), (6) показує, що $K=1 / N_{K}$, де $N_{K}$ - значення $N_{1}$, при якому дотична до кривої (5) перетинає рівень $P=1$.

Розглянемо ситуацію з іншої точки зору, приймаючи до уваги, що при розв'язанні практичних задач оперують швидкістю надходження інформації $C_{11}$. Тоді за час $t$ надходить інформація $I_{1}=C_{11} t$. Оскільки $d I_{1} / d t=C_{11}, I_{1}=\ln N_{1}$, то можна записати

$$
\frac{d N_{1}}{d t}=C_{11} N_{1}
$$

Необхідно зауважити, що рівняння (7) є інформаційним аналогом рівняння Т. Мальтуса [12]. Таким чином, існує можливість скористатися методом аналогій та поширити отримані результати на інші математичні моделі. Відомо, що в умовах самолімітування використовують модель КетлеФерхюльста. Приймемо до уваги, що при $N_{1}=1$ кількість інформації $I_{1}=\ln N_{1}=0$. Тоді у праву частину рівняння Кетле-Ферхюльста необхідно ввести складову $N_{1}-1$, оскільки відлік починається від значення $N_{1}=1$. Таким чином, інформаційний аналог вказаної моделі

$$
\frac{d N_{1}}{d t}=C_{11} N_{1}\left(1-\frac{N_{1}-1}{M-1}\right)
$$

Потенційно можливе максимальне значення $N_{1}$ визначається із умови

$$
M=\lim _{t \rightarrow \infty} N_{1}(t) .
$$

Врахуємо фактор впливу відволікаючої та заважаючої інформації $I_{2}=\ln N_{2}$. Тоді за аналогією 3 рівнянням (8) запишемо

$$
\frac{d N_{1}}{d t}=C_{11} N_{1}\left(1-\frac{N_{2}-1}{M_{2}-1}\right) .
$$

Потенційно можливе максимальне значення $N_{2}$ визначається із умови

$$
M_{2}=\lim _{t \rightarrow \infty} N_{2}(t) \text {. }
$$

Перепишемо співвідношення (9) у вигляді

$$
\frac{d N_{1}}{d t}=\frac{C_{11} N_{1}}{M_{2}-1}\left(M_{2}-N_{2}\right) \text {. }
$$


Аналіз рівняння (10) показує, що за умови відсутності відволікаючої та заважаючої інформації (тобто при $N_{2}=1, I_{2}=\ln N_{2}=0$ ) залежність $N_{1}$ від $N_{2}$ відсутня, і має місце умова (7).

Таким чином, на підставі методу аналогій отримано математичну модель, яка дає можливість врахувати фактор релевантності у інформаційному забезпеченні фрахівців. На підставі залежності (10) необхідно визначити закономірності зміни $N_{1}$ та $N_{2}$, встановити їх зв'язок з показником релевантності і врахувати фактор часу.

\section{III Результати}

Приймемо до уваги рівняння (10) та скористуємося відомою методикою [13]. Введемо у розгляд величину $x=x(t)$, коефріцієнт $a>0$ та запишемо

$$
N_{1}=1+x, N_{2}=1+a x .
$$

На підставі залежностей (10), (11) знаходимо

$$
\frac{d x}{(1+x)\left(M_{2}-1-a x\right)}=\frac{C_{11} d t}{M_{2}-1} .
$$

Після перетворень рівняння (12) набуває вигляду

$$
\left(\frac{1}{1+x}+\frac{a}{M_{2}-1-a x}\right) d x=\frac{C_{11}\left(M_{2}-1+a\right) d t}{M_{2}-1} .
$$

Інтегруючи ліву частину рівняння (13) від 0 до $x$, а праву від 0 до $t$, знаходимо

$$
\begin{gathered}
x=\frac{\left(M_{2}-1\right)[1-\exp (-D t)]}{a+\left(M_{2}-1\right) \exp (-D t)}, \\
D=\frac{C_{11}\left(M_{2}-1+a\right)}{\left(M_{2}-1\right)} .
\end{gathered}
$$

На підставі залежностей (14), (15) визначаємо усталене значення

$$
x_{c m}=\lim _{t \rightarrow \infty} x(t)=\frac{M_{2}-1}{a} .
$$

Прийнявши до уваги залежність (11), позначимо $M_{1}=1+x_{c m}$. Тоді на підставі рівняння (16) можна записати

$$
M_{1}=1+\frac{M_{2}-1}{a} .
$$

Приймаючи до уваги залежність (17), визначаємо

$$
a=\frac{M_{2}-1}{M_{1}-1} .
$$

Введемо у розгляд показник релевантності

$$
R=\frac{M_{1}}{M_{1}+M_{2}} .
$$

На підставі залежностей (18), (19) знаходимо 


$$
R=\frac{M_{1}}{M_{1}+1+a\left(M_{1}-1\right)} \text {. }
$$

Якщо $M_{1} \gg 1$, то $R \approx 1 /(1+a)$.

Формули (19), (20) описують значення $R$ у довгостроковій перспективі. Розглянемо ситуацію у динаміці. По аналогії з формулою (19) запишемо

$$
R_{1}=\frac{N_{1}}{N_{1}+N_{2}}
$$

На підставі залежностей (11), (21) знаходимо

$$
R_{1}=\frac{1+x}{2+(1+a) x}
$$

Приймаючи до уваги співвідношення (20), (22) визначаємо

$$
R_{1}=\frac{R\left(M_{1}-1\right)(1+x)}{2 R\left(M_{1}-1\right)+x\left(M_{1}-2 R\right)}
$$

Якщо $M_{1} \gg 1$, то на підставі співвідношення (23) знаходимо

$$
R_{1} \approx \frac{1+x}{2+\frac{x}{R}}
$$

Врахуємо усталене значення величини $x$. Тоді на підставі залежностей (14), (15), (16) знаходимо

$$
\begin{gathered}
x=\frac{x_{c m}[1-\exp (-D t)]}{1+x_{c m} \exp (-D t)}, \\
D=\frac{a C_{11}\left(x_{c m}-1\right)}{x_{c m}} .
\end{gathered}
$$

Таким чином, співвідношення (23), (24), (25) дають можливість встановити зв'язок між поточним значенням показника релевантності та його значенням у довгостроковій перспективі.

\section{IV Обговорення}

Приймаючи до уваги залежності (18), (20), проведено класифікацію впливів відволікаючої та заважаючої інформації (табл. 1).

Поточне значення показника релевантності можна визначити із залежності (23). Аналіз залежностей (24), (25) показує, що в процесі розрахунків доцільно оперувати поточним та усталеним значеннями змінних величин. Це дає можливість визначити прогнозну тенденцію та скласти прогнозну модель. В межах оперативного аналізу доцільно проводити контрольні заходи у декількох точках. Виберемо такі точки, де величина $x$ визначається із умови $x=r x_{c m}, r<1$. 
Табл. 1. Класифікація впливів відволікаючої та заважаючої інформації

\begin{tabular}{|c|c|c|c|}
\hline Параметри $M_{1}, M_{2}$ & Параметр $a$ & $\begin{array}{c}\text { Показник } \\
\text { релевантності }\end{array}$ & $\begin{array}{c}\text { Характер впливу } \\
\text { відволікаючої та заважаючої } \\
\text { інформації }\end{array}$ \\
\hline$M_{2}>M_{1}$ & $a>1$ & $0<R<0.5$ & Превалюючий вплив \\
\hline$M_{2}=M_{1}$ & $a=1$ & $R=0.5$ & Рівнозначний вплив \\
\hline$M_{2}<M_{1}$ & $0<a<1$ & $0.5<R<1$ & Непревалюючий вплив \\
\hline
\end{tabular}

На підставі залежності (23) за умови $M_{1} \gg 1$ маємо

$$
R_{1 r} \approx \frac{1+r x_{c m}}{2+\frac{r x_{c m}}{R}} .
$$

Таким чином, можна провести оперативну оцінку показника релевантності у заздалегідь передбачених контрольних точках, врахувати швидкість надходження інформації $C_{11}$ і характер впливу відволікаючої та заважаючої інформації.

Визначимо час досягання контрольних значень величини $x$. Приймаючи до уваги залежність (24) та умову $x=r x_{c m}$ для контрольного часу $t_{r}$ знаходимо

$$
r x_{c m}=\frac{x_{c m}\left[1-\exp \left(-D t_{r}\right)\right]}{1+x_{c m} \exp \left(-D t_{r}\right)} .
$$

На підставі співвідношень (25), (26) визначаємо

$$
t_{r}=\frac{x_{c m}}{a C_{11}\left(x_{c m}-1\right)} \ln \frac{r x_{c m}+1}{1-r},
$$

де величина $C_{11}$ визначається в умовах, коли відсутня відволікаюча та заважаюча інформація, і вимірюється у ніт/с.

Для проведення аналізу можна вибрати $r=0.1 ; r=0.5 ; r=0.9$. Розглянемо ситуацію, коли $x_{c m} \gg 1$ та $r=0.5$. Перейдемо від ніт/с до біт/с, скористуємося залежністю (27), позначимо $L=\log _{2} x_{c m}$ та запишемо

$$
t_{0.5} \approx \frac{L}{a C_{11}}
$$

Зауважимо, що відповідно до співвідношення (16) величина $x_{c m}$ зменшується із збільшенням $a$. Нехай фахівець працює з текстовою інформацією за умови $C_{11}=4$ біт/с. Потенційні можливості $L=10^{5}$ біт. Тоді для непревалюючих впливів $(a=0.1)$ на підставі співвідношення (28) знаходимо $t_{0.5} \approx 69$ годин 26 хвилин. Аналогічні розрахунки можна виконати для превалюючого та рівнозначного впливів.

Після того, як визначено час досягнення $t_{r}$ контрольного значення $x=r x_{c m}$, тобто враховано фактор часу, можна провести процедуру оперативного оцінювання показника релевантності та розширити зміст таблиці 1. В області превалюючих впливів відволікаючої та заважаючої інформації виділяються дуже сильні впливи $(a \gg 1)$. Така ситуація спостерігається в умовах агресивних інформаційних технологій. В області непревалюючих впливів відволікаючої та заважаючої інформації виділяються дуже слабкі впливи $(a \ll 1)$. Така ситуація характерна для незначного впливу відволікаючої та заважаючої інформації. Суттєвим фактором $€$ також вміння фрахівця зосереджуватися саме на корисній інформації. 
Скористуємося залежністю (22) та приймемо до уваги, що $x=r x_{c m}$. Тоді можна записати

$$
R_{1 r}=\frac{1+r x_{c m}}{2+(1+a) r x_{c m}}
$$

Для умови дуже сильних впливів відволікаючої та заважаючої інформації ( $a \gg 1)$ на підставі формули (29) визначаємо

$$
R_{1 r} \approx \frac{1+r x_{c m}}{2+a r x_{c m}}
$$

Для дуже слабких впливів відволікаючої та заважаючої інформації ( $a \ll 1)$ на підставі формули (29) знаходимо

$$
R_{1 r} \approx \frac{1+r x_{c m}}{2+r x_{c m}}
$$

Зауважимо, що в умовах дуже сильних впливів відволікаючої та заважаючої інформації ситуація стає критичною (величина $R_{1 r} \in$ дуже малою).

3'ясуємо прогнозні перспективи відносно ймовірності виконання поставленої перед фахівцем задачі. Приймемо до уваги, що $M_{1}=1+x_{c m}, M_{1}=N_{1 c m}$. Тоді на підставі залежності (5) знаходимо

$$
P_{c m}=1-\left(1+x_{c m}\right)^{-K} \text {. }
$$

Таким чином, використовуючи дані щодо величини $x_{c m}$, згідно формул (30), (31), (32) можна визначити необхідні показники, які характеризують рівень інформаційного забезпечення фахівця.

\section{V Висновки}

Отримані результати показують, що оцінити релевантність інформації можна на підставі використання прогнозних моделей, які враховують співвідношення між корисною, заважаючою і відволікаючою інформацією, та складаються виходячи із аналогій з популяційними моделями. Такий підхід дає можливість скористатися відомими методами аналізу та скласти рівняння інформаційної динаміки, які враховують фактори самолімітування, зовнішнього лімітування та швидкість надходження інформації в ідеальних умовах.

Запропоновану методику оцінки релевантності інформації спрямовано на визначення реальних та потенційних можливостей фахівця, який виконує поставлену задачу та приймає рішення в умовах дії заважаючих та відволікаючих впливів. Таким чином, співвідношення (19), (20), (23) для показника релевантності можна розглядати як кількісну оцінку наслідків впливу заважаючої та відволікаючої інформації. Проведена класиффікація впливів (табл. 1) дає можливість пов'язати параметри $M_{1}, M_{2}, a$, $R$ з характером впливу та визначати прогнозні тенденції.

Поточні значення релевантності $R_{1}$ доцільно контролювати у декількох точках відносно усталеного значення. Такий підхід дає можливість оперативно визначати контрольні показники та визначати час, через який їх буде досягнуто.

Процедуру оперативного оцінювання показника релевантності доцільно розглядати окремо для дуже сильних та дуже слабких впливів відволікаючої та заважаючої інформації. У даних випадках проводяться досить прості розрахунки.

Необхідно зауважити, що запропонована методика оцінки релевантності інформації може доповнити існуючи підходи до оцінки роботи персоналу в критичних ситуаціях, які виникають внаслідок реалізації агресивних інформаційних технологій. Фахівці, які виконують поставлені задачі та приймають рішення на підставі отриманої інформації, по-різному реагують на заважаючи та відволікаючи впливи. Таким чином, для кожного фахівця величина $a$, яка знаходиться із умови (18), буде різною. Фахівці, що мають велику інформаційну компетентність, здатні зосереджуватися на корисній інформації та мало 
реагувати на заважаючу та відволікаючу інформацію. Для таких фахівців $a \ll 1$. Інша група фахівців характеризується низькою інформаційною компетентністю, тобто суттєвою величиною $a$. Приймаючи до уваги залежність (20), можна зробити висновок, що у прогнозній перспективі $a=\left[M_{1}-R\left(M_{1}+1\right)\right] / R\left(M_{1}-1\right)$. Таким чином, показники $M_{1}$ та $R$ дають можливість на підставі отриманого значення величини а провести оцінку інформаційної компетентності фахівця та доповнити існуючи методи оцінки персоналу $[14,15,16] .3$ іншого боку, можна удосконалити арсенал інструментів оцінки персоналу [17, 18].

Приймемо до уваги, що у наш час постійно розвиваються технології оцінювання професійних можливостей фахівців та студентів $[19,20]$. Виконання поставлених перед фахівцями та студентами завдань не представляється можливим без вміння та досвіду використання необхідної інформації. Таким чином, отримані результати доповнюють відомі методи оцінки релевантності інформації і можуть також використовуватися в процесі відбору персоналу та проведення самооцінки з метою визначення подальшого розвитку.

\section{Бібліографрічні посилання}

1. Ожерельева Т. А. Об отношении понятий «информационное пространство», «информационное поле», информационная среда» и «семантическое окружение» / Международный журнал прикладных и фундаментальных исследований, 2014. № 10-2. С. 21-24.

2. Сергеев С. Ф. Инструменты обучающей среды: интеллект и когнитивные стили / Образовательные технологии, 2010, № 10-24. С. 28-39.

3. Смирнов М. А. Информационная среда и развитие общества. / Интеллектуальное общество, 2001. Вып. 5. С. 50-54.

4. Аллахвердов В. М. Когнитивная психология сознания / Вестник Санкт-Петербургского университета. Серия 16. Психология. Педагогика, 2012. № 2. С. 50-59.

5. Овсянникова В. В. Когнитивные стратегии распознавания эмоциональных состояний / Сибирский психологический журнал, 2007. № 25. С. 40-46.

6. Згуровський М. 3., Панкратова Н. Д. Основи системного аналізу. К. : Видавнича група ВНV, 2007. 544 с.

7. Saracevic, Tefko (2007). Relevance: A review of the literature and a framework for thinking on the notion in information science. Part II: Nature and manifestations of relevance / Journal of the American Society for Information Science and Technology. Iss. 58(13): 1915-1933. DOI: 10.1002/asi.20682

8. Saracevic, Tefko (2007). Relevance: A review of the literature and a framework for thinking on the notion in information science. Part III: Behavior and effects of relevance / Journal of the American Society for Information Science and Technology. Iss. 58(13): 2126-2144. DOI: 10.1002/asi.20681

9. Saracevic, T. (2012). Research on relevance in information science: A historical perspective. In; Carbo, T. \& Bellardo Hahn, T. (Eds). Proceedings of the American Society for Information Science and Technology (ASIS\&T) 2012 Preconference on the History of ASIS\&T and Information Science and Technology. pp. 49-60.

10. Коган И. М. Прикладная теория информации. Москва: Радио и связь, 1981. 216 с.

11. Кузнєцов Ю. М., Скляров Р. А. Прогнозування розвитку технічних систем. К. : ТОВ «ЗМОК» - ПП «ГНОЗИС», 2004. 323 c.

12. Долгий Ю. Ф., Сурков П. Г. Математические модели динамических систем с запаздыванием. Екатиренбург: Издательство уральского университета, 2012. 122 с.

13. Стромберг А. Г., Семченко Д. П. Физическая химия / Под ред. А.Г. Стромберга. Москва: Вісшая школа, 1988.496 с.

14. Вулкович-Стадник А. А. Оценка персонала: четкий алгоритм действий и качественные практические. М. : Эксмо, 2008. 192 C.

15. Иванова С. В. Кандидат, новичок, сотрудник. Инструменты управления персоналом, которые реально работают на практике. М. : Эксмо, 2008. 304 с.

16. Киселева Н. М. Оценка персонала. Санкт-Петербург: Питер, 2015. 173 с.

17. Bienzeisler B. (2005) Die Competence Card als Mess- und Steuerungsinstrument für die Dienstleistungswirtschaft. Praxishandbuch Controlling, pp. 167-183. doi: https://doi.org/10.1007/978-3-322-90505-5_6

18. Бурлачук Л. Ф., Володина Н. П. Оценка персонала: проблема выбора инструментов / ЭКО. 2003. №11. С. 89-104.

19. Aggarwal A., Thakur G. S. M. (2013) Techniques of Performance Appraisal-A Review / International Journal of Engineering and Advanced Technology (IJEAT). Volume 2. Iss. 3, pp. 617-621.

20. Baughman J. A., Brumm Th. J., Mickelson S. K. (2012) Student Professional Development: Competency-Based Learning and Assessment / The Journal of Technology Studies. 2012. Vol. 38. Iss. 2, pp. 115-127. 


\section{References}

1. Ozherel'eva, T. A. (2014). On the relationship between the concepts "information space", "information field", "information environment" and "semantic environment" [Obotnoshenii ponyatij «informacionnoe prostranstvo», «informacionnoe pole», informacionnaya sreda» i "semanticheskoe okruzhenie»]. International Journal of Applied and Basic Research [Mezhdunarodnyj zhurnal prikladnyh i fundamental'nyh issledovanij], 10-2, 21-24. [in Russian]

2. Sergeev, S. F. (2010). Learning Environment Tools: Intelligence and Cognitive Styles [Instrumenty obuchayushchej sredy: intellekt i kognitivnye stili]. Educational technologies [Obrazovatel'nye tekhnologii], 10-24, 28-39. [in Russian]

3. Smirnov, M. A. (2001). Information environment and development of society [Informacionnaya sreda i razvitie obshchestva]. I/ Intellectual society [Intellektual'noe obshchestvo], 5, 50-54.

4. Allahverdov, V. M. (2012). Cognitive psychology of consciousness [Kognitivnaya psihologiya soznaniya]. Vestnik SanktPeterburgskogo universiteta. Seriya 16. Psihologiya. Pedagogika, 2, 50-59. [in Russian]

5. Ovsyannikova, V. V. (2007). Cognitive strategies for recognizing emotional states [Kognitivnye strategii raspoznavaniya emocional'nyh sostoyanij]. Sibirskij psihologicheskij zhurnal, 25, 40-46. [in Russian]

6. Zghurovskyi, M. Z., Pankratova, N. D. (2007). Fundamentals of System Analysis [Osnovy systemnoho analizu]. Vydavnycha hrupa BHV, Kyiv, 544. [in Ukrainian]

7. Saracevic, Tefko (2007). Relevance: A review of the literature and a framework for thinking on the notion in information science. Part II: Nature and manifestations of relevance. Journal of the American Society for Information Science and Technology, 58(13), 1915-1933. DOI: 10.1002/asi.20682.

8. Saracevic, Tefko (2007). Relevance: A review of the literature and a framework for thinking on the notion in information science. Part III: Behavior and effects of relevance. Journal of the American Society for Information Science and Technology. 58(13), 2126-2144. DOI: 10.1002/asi.20681.

9. Saracevic, T. (2012). Research on relevance in information science: A historical perspective. In; Carbo, T. \& Bellardo Hahn, T. (Eds). Proceedings of the American Society for Information Science and Technology (ASIS\&T). Preconference on the History of ASIS\&T and Information Science and Technology, 49-60.

10. Kogan, I. M. (1981). Applied Information Theory [ Prikladnaya teoriya informacii]. Radio i svyaz', Moskva, 216. [in Russian]

11. Kuznietsov, Yu. M., Skliarov, R. A. (2004). Predicting the development of technical systems [Prohnozuvannia rozvytku tekhnichnykh system]. TOV «ZMOK» - PP «HNOZYS», Kyiv, 323. [in Ukrainian]

12. Dolgij, Yu. F., Surkov, P. G. (2012). Mathematical models of dynamical systems with delay [Matematicheskie modeli dinamicheskih sistem s zapazdyvaniem]. Ekatirenburg, Izdatel'stvo ural'skogo universiteta, 122. [in Russian]

13. Stromberg, A. G., Semchenko, D. P. (1988). Physical chemistry [Fizicheskaya himiya]. Visshaya shkola, Moscow, 496. [in Russian]

14. Vulkovich-Stadnik, A. A. (2008), Personnel assessment: a clear algorithm of actions and high-quality practical solutions [Ocenka personala: chetkij algoritm dejstvij i kachestvennye prakticheskie resheniya]. Eksmo, Moscow, Russia, 192. [in Russian]

15. Ivanova, S. V. (2008). Candidate, beginner, employee. HR tools that really work in practice [Kandidat, novichok, sotrudnik. Instrumenty upravleniya personalom, kotorye real'no rabotayut na praktike]. Eksmo, Moscow, Russia, 304. [in Russian]

16. Kiseleva, M. N. (2015). Personel assessment [Ocenka personala]. Piter, Sankt-Peterburg, Russia, 173. [in Russian]

17. Bienzeisler, B. (2005), Die Competence Card als Mess- und Steuerungsinstrument für die Dienstleistungswirtschaft. Praxishandbuch Controlling, 167-183. doi: https://doi.org/10.1007/978-3-322-90505-5_6.

18. Burlachuk, I. F., Volodina, N. P. (2003). Personnel assessment: the problem of choosing tools [Ocenka personala: problema vybora instrumentov]. Eko, 11, 89-104. [in Russian]

19. Aggarwal, A., Thakur, G. S. M. (2013). Techniques of Performance Appraisal-A Review. International Journal of Engineering and Advanced Technology (IJEAT), 2(3), 617-621.

20. Baughman, J. A., Brumm, Th. J., Mickelson, S. K. (2012), Student Professional Development: Competency-Based Learning and Assessment. The Journal of Technology Studies, 38(2), 115-127.

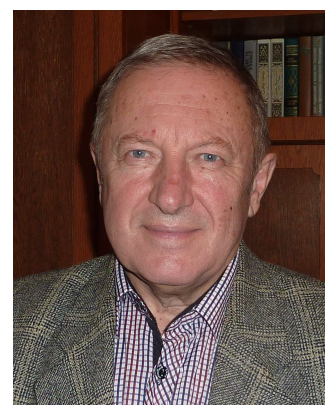

Бичковський Владислав Олексійович,

к.техн.Н., доцент, доцент кафедри радіотехнічних пристроїв та систем,

Національний технічний університет України «Київський політехнічний інститут імені Ігоря

Сікорського»,

пр. Перемоги 37, 17-й корпус НТУУ «КПІ ім. Ігоря Сікорського», Київ, Україна, 03056.

Тел. +38(050) 163-75-88. E-mail: marina060709@gmail.com

Bychkovskyi Vladyslav Oleksiyovych,

Cand.Sc. (Eng.), Associate Professor, Associate Professor of Radiotechnical Devices and Systems

Department,

National Technical University of Ukraine «lgor Sikorsky Kyiv Polytechnic Institute»

Vul. Politechnical, 12, 17th building of NTUU «KPI them. Igor Sikorsky», Kyiv, Ukraine, 03056.

Tel. +38(050) 163-75-88. E-mail: bychkovskij.vlad@gmail.com

ORCID: 0000-0003-1065-4924

Researcher ID: I-4729-2018 


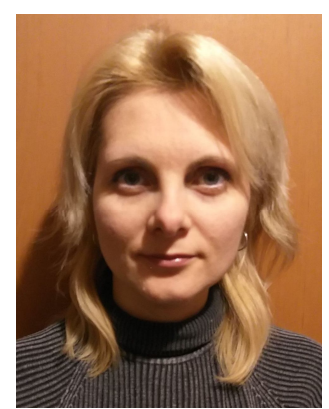

\section{Реутська Юлія Юріївна,}

старший викладач кафедри комп'ютерних наук,

Національний університет біоресурсів і природокористування України,

вул. Героїв Оборони, 16а, навчальний корпус 15, Київ, Україна, 03041

асистент кафедри загальної та теоретичної фізики,

Національний технічний університет України «Київський політехнічний інститут імені Ігоря

Сікорського»,

пр. Перемоги 37, 7-й корпус НТУУ «КП ім. Ігоря Сікорського», Київ, Україна, 03056.

Тел. +38(093) 547-58-02. E-mail: reutska_rtf@ukr.net

\section{Reutska Yuliia Yuriivna}

Senior Lecturer of Computer Science Department,

National University of Life and Environmental Sciences of Ukraine

16a Heroyiv Oborony St., 15th building of NUBiP, Kyiv, Ukraine, 03041.

Assistant of General and Theoretical Physics Department,

National Technical University of Ukraine «lgor Sikorsky Kyiv Polytechnic Institute»

Vul. Politechnical, 12, 7th building of NTUU «KPI them. Igor Sikorsky», Kyiv, Ukraine, 03056.

Tel. +38(093) 547-58-02. E-mail: reutska_rt@ukr.net

ORCID: 0000-0003-1954-9100

Researcher ID: I-4652-2018

\section{Citation (APA):}

Bychkovskyi, V., Reutska, Yu. (2021). Methodology of information relevance assessment. Engineering and Educational Technologies, 9 (1), 78-88. doi: https://doi.org/10.30929/2307-9770.2021.09.01.07

\section{Цитування (ДСТУ 8302:2015):}

Бичковський В. О., Реутська Ю. Ю. Методика оцінки релевантності інформації / Інженерні та освітні технології. 2021. Т. 9. № 1. C. $78-88$. doi: https://doi.org/10.30929/2307-9770.2021.09.01.07

Обсяг статmі: сторінок - 11 ; умовних друк. аркушів - 1,593. 


\section{PSYCHOLOGICAL PROBLEMS AT MODERN EDUCATION}

\section{ПСИХОЛОГІЧНІ ПРОБЛЕМИ СУЧАСНОЇ ОСВІТИ}

